\title{
Public Economics and History: A Review of Fiscal Regimes and the Political Economy of Premodern States, Edited by Andrew Monson and Walter Scheidel
}

\author{
Philip T. HofFMan*
}

\begin{abstract}
Fiscal Regimes and the Political Economy of Premodern States greatly expands our knowledge of the history of premodern fiscal systems and raises important questions about the political economy of premodern states. Answering those questions can help explain how states developed the capacity to tax; why tax levels and government-spending patterns varied greatly in the past, even though per capita incomes were similar; how government debt and representative institutions arose; and, last but not least, why some premodern states expanded and others collapsed. But firm answers to those questions will have to combine the history outlined in Fiscal Regimes and the Political Economy of Premodern States with systematic data and formal models of political economy. (JEL E62, H20, H50, N40)
\end{abstract}

\section{Introduction}

$\Psi_{\mathrm{f}}^{\mathrm{f}}$ f public economics today can study all the 1 manifold things modern states do (taxing, spending, regulating, intervening to correct market failures, implementing macroeconomic policy), its scope of analysis in the past might seem severely limited, for by modern standards, the range of government action was more narrow then than it is today. But

\footnotetext{
* California Institute of Technology.

${ }^{\dagger}$ Go to https://doi.org/10.1257/jel.20151348 to visit the article page and view author disclosure statement.
}

the public economics of the past still have much to tell us about why states rise and fall, how they overcome serious problems of tax evasion and tax resistance and develop the capacity to tax, the effect their policies have on financial development and economic growth, and-above all else-about the political economy behind their policies. And it can answer big questions about the political economy of premodern states: Why did some the states expand and others collapse? Why did per capita tax levels (and to a lesser degree, public-goods provision) vary greatly across states and over time in the distant past, even though per capita incomes 
were roughly the same? And why did financial markets and representative institutions arrive early in the West? The answers are not only fascinating intellectually; they may shed light on economic growth and political development in low-income countries that face similar problems of establishing state capacity and providing fundamental public goods such as security.

Getting to the bottom of those questions, though, is not simple; it takes several steps. The first is to get the history right for a large sample of past states. Only then can one construct economic models, gather systematic data, test hypotheses, and ultimately answer the big questions about political economy. The recent publication of Fiscal Regimes and the Political Economy of Premodern States (Cambridge University Press), edited by Andrew Monson and Walter Scheidel, constitutes a major achievement in completing the first step of the process. With nineteen meticulous chapters spanning back five millennia and covering states in East Asia, the Middle East, Europe, and pre-Columbian America, the book greatly expands our knowledge of premodern fiscal systems and political economy. The authors, who come from five disciplines (archeology, history, economics, political science, and sociology), are all experts on the historical fiscal systems that they are writing about. They have the requisite skills: they are familiar with the institutional intricacies of the society they are writing about, and almost all of them know the languages of the relevant historical sources. Readers can therefore be confident that their chapters provide a trustworthy guide to the history, and with their book in print, it is now possible to take the next steps toward answering our questions.

After explaining in detail what the book tells us and how it broadens our knowledge, this review explores the questions it raises about the political economy of premodern states and the tentative answers that it points to. The major lesson to draw from the book is that we now need systematic data that will make possible comparisons across different historical examples. Time series of annual government tax receipts or annual government expenditures by category will be impossible; it is difficult to assemble that sort of empirical evidence even for many nineteenth-century states. But limited quantitative data is feasible, such as periodic estimates of total tax receipts per capita or total spending per capita, along with measures of what the spending paid for, such as the number of soldiers mobilized, kilometers of fortifications constructed, or canals dug. Qualitative data can be turned into systematic econometric evidence too: Do representative institutions exist? Does the state borrow? Does it provide famine relief or pay to construct temples or churches? Obviously some of the qualitative or quantitative data could come from archeology.

Fiscal Regimes and the Political Economy of Premodern States also makes it clear that we need to construct formal models that can be combined with the systematic evidence and used to formulate and test hypotheses. The starting point for the modeling could be a central problem that crops up repeatedly in the book: namely, the problem confronting a political leader (a king, for instance) who makes decisions about taxes or spendingsubject to certain political constraints-in order to achieve some goal, such as winning a war. Since few of the states described in the book were democracies, the political constraints usually did not involve winning the support of a majority of voters. Rather, they turned on gaining the support of pivotal members of the elite or avoiding revolts or other political costs. The issue, then, is whether the state's fiscal system emerged as the solution to the mechanism design problem facing the political leader or whether it was instead shaped primarily by history and existing institutions. Getting to the bottom of 
that issue can lead us to answers for most of our questions about the political economy of premodern states, but as we shall see, it will require not just systematic data and theory, but also a deep knowledge of the relevant history.

2. Overview of Fiscal Regimes and the Political Economy of Premodern States

Fiscal Regimes and the Political Economy of Premodern States is not the first work on the topic. There already exists a literature in economic history and political science on this subject-a literature that reaches back to Schumpeter's "Crisis of the Tax State" (1918) and the pioneering research done by the historian Patrick O'Brien (Mathias and O'Brien 1976, O'Brien 1988) and the historical sociologist Charles Tilly (1990). But until recently, most of this literature has been limited to case studies of Western Europe in the years 1500 to 1800 -what historians call the early modern period (O'Brien 1988; Hoffman and Norberg 1994; Bonney 1995, 1999; Hoffman and Rosenthal 1997; Rosenthal 1998; Ormrod, Bonney, and Bonney 1999; Yun-Casalilla and O'Brien 2012). Those limits made sense because it was during that period that most states in Western Europe first developed fiscal systems able to raise substantial amounts of permanent tax revenue. The historical records for European states in that period were often abundant, too. But the focus on early modern Europe could easily be misleading, and it could be downright dangerous for anyone who took the European examples as stylized facts and then tried to build a model of premodern fiscal systems. One of the virtues of Fiscal Regimes and the Political Economy of Premodern States is that the book makes that danger clear.

The reason the examples from early modern Europe could be misleading is that they were unusual on many counts, even by the standards of the premodern era. To begin with, they imposed very heavy taxes by premodern standards: in 1776, for example, per capita taxes (measured in silver) in France were 8.7 times what they were in China; in England, they were 25.6 times Chinese per capita taxes. The results are similar if we compare longer periods or different years, or measure per capita taxes in man-days of unskilled labor (Hoffman 2015b, pp. 50-51; Brandt, Ma, and Rawski 2014, table 3). Taxes are much lower in the eighteenth-century Ottoman Empire, too (Karaman and Pamuk 2010), and in both China and the Ottoman Empire, differences in per capita incomes and the frequency of war cannot explain the huge gap in per capita tax receipts.

Nor is that the only peculiar feature of fiscal regimes in early modern Europe. The early modern states spent heavily on the military (Dincecco 2011; Hoffman and Rosenthal 1997). In Prussia, for example, we can separate out annual military expenditures as a fraction of total government spending for the period 1688 through 1789; for those years, the median figure was 90 percent. In France, the median was 73 percent for the years 1600-1688, and much of the remaining spending was devoted to interest on debts run up in wars (Hoffman 2015a, pp. 314-15). By comparison, a similar calculation for the US federal government for the period 1791-1970 yielded a median of only 43 percent (Carter et al. 2006).

Military spending was high in these early modern European states not just because of frequent military conflict, but because the political leaders who made decisions about war and military spending were typically kings who had been raised to fight for goals, such as glory on the battlefield or victory over enemies of the faith, that were impossible to divide up by peaceful bargaining. War, for them, was at least in part a consumption good, and because they avoided most of the costs of fighting and reaped a 
disproportionate share of the benefits, they were extremely likely to engage in conflict (Hoffman 2015a, 2015b; Jackson and Morelli 2007).

Apart from defense, these early modern European states provided little in the way of public goods. They did make available a means of exchange-coins-although their value was rarely stable. They also provided courts to resolve disputes and try criminals, but these courts were often funded via fees imposed on the litigants, and the lowest jurisdictions often remained in private hands. As for transportation infrastructure, the early modern European states built few roads, canals, or other transportation improvements. There were some exceptions, but exceptions often involved military transport. They did little for water control either-that was typically the province of local authorities_and often they failed even to resolve disputes over property rights that kept locally sanctioned water projects from going forward (Rosenthal 1992). They spent almost nothing on education and poor relief, either (Lindert 2004), and they by and large left the construction of churches and religious buildings to private donors.

The fiscal systems in early modern Europe had one other distinguishing feature. The rulers in many of the states moved from relying on revenue from their own personal property (their domain, to use historians' language) to taxes imposed on their subjects' property. This shift from what historians would call a "domain state" to a "tax state" followed up on an even earlier transition in the Middle Ages, which saw military leaders turn to income from their own domain instead of extracting tribute from conquered territory. There is no economic theory behind this pattern of a tax state following a domain state and an even earlier tribute state, but it seemed to fit much of European history (Ormrod, Bonney, and Bonney 1999).
The authors of Fiscal Regimes and the Political Economy of Premodern States know that early modern Europe was unusual. And as the introduction to the volume (by the historians of the Greco-Roman world, Andrew Monson and Walter Scheidel) makes clear, the book's authors want to break free from reliance on early modern European examples-in particular the pattern of a transition from tribute to a domain state and from there to a tax state. That is one of the chief motives behind their effort to extend the account of premodern fiscal regimes and political economy to other continents and further back in time. Although there is almost no formal economic theory in the volume (the one exception is the brief sketch of a simple model in the economist Metin Cosgel's excellent chapter on the Ottoman Empire), there is, as we shall see, one recurrent theme-the principal-agent problem facing a political leader who makes decisions about taxes or spending in order to achieve some goal. In making the decisions, the leader has to take into account political constraints and the actions of agents who might be officials, members of the social or political elite, or even - in the rare premodern democracies-voters. That theme, in turn, may help to explain other patterns that crop up in the book: for instance, that per capita taxes were often low in large states, because they confronted severe agency problems in distant provinces and were too big to face significant external threats that would have justified higher tax rates.

The first part of the book examines the fiscal systems of the Inca Empire, the Aztec Empire, and the polities of the ancient Near East and Egypt. All were what the editors call "extractive" fiscal regimes, in the sense that they all relied heavily on taxes paid in the form of labor services. In the Inca Empire, Terence N. D'Altroy estimates that labor duties amounted to 40 percent of the labor supply, and besides drawing on labor duties, 
the state resettled three to five million people. Politically untrustworthy populations on the edge of the empire escaped most of the tax burden. The labor services demanded of the rest of the population were used not just to field armies of over 100,000 men (large even by contemporary European standards), but to undertake water control projects and build roads and agricultural terracing-state infrastructure spending of a sort that was unknown in early modern Europe.

In the Aztec Empire, distant provinces also paid lower taxes. When compared with early modern Europe, the Aztec regime mixed characteristics of a domain state and a tax state. But there was one striking difference that set the Aztecs apart from the premodern Europeans, according to the author of the chapter on the Aztecs, Michael E. Smith: the Aztec kings seem not to have used increased tax revenues to boost the size of their armies.

Rulers in the ancient Near East and Egypt seemed to spend even less on war. Rulers there (so historians Michael Jursa and Juan Carlos Moreno García claim in their chapter) did support the military, but they devoted even more of their labor services and tax revenue to religion, redistribution for the elite, irrigation, and water control. The spending on such public-works projects is yet another contrast with premodern Europe.

The second section of the book comprises six chapters on the Roman Republic, the Roman Empire, the Hellenistic Empires of the ancient Mediterranean, and Imperial China from the first dynasty, the Qin $(221 \mathrm{BC}$ to $206 \mathrm{BC}$ ), to the last, the Qing (1644-1912). Themes that run throughout these chapters include the effects of political fragmentation and imperial unification, and the recurrent political struggle between central authorities and local elites over what share of rent would be paid in taxes and what portion would remain in the hands of local elites.

In Andrew Monson's chapter on the Hellenistic Empires of the ancient
Mediterranean, the threat of external enemies drove taxes (mostly on land and often farmed out) to high levels. But raising taxes could also generate competition with elites and even cause empires to collapse. By contrast, taxes in the Roman Empire, as Monson notes, were usually low, particularly in Italy. The reason, he suggests, is that Roman emperors enjoyed unmatched military supremacy and they could reward local elites with fiscal privileges.

The republic that gave rise to the Roman Empire was a city-state whose citizens enjoyed freedom from taxation. Its decentralized political system, historian James Tan argues, discouraged political leaders from freely spending public funds, and elites feared the rise of a powerful centralized state and so kept individuals or factions from gaining control of the treasury. Although the Roman Republic did borrow, it had little tax infrastructure, and much tax collection was farmed out.

Two chapters by Walter Scheidel and Gilles Bransbourg examine what happens when the Roman Republic became an empire. The first step was a military dictatorship with a large standing army, a small bureaucracy, and the cooperation of the elite. Initially, the lack of serious external threats meant that taxes were generally low, and the populace in Rome itself were placated with the free distribution of grain. After the second century, pressure from foreign enemies led to tax increases, and even before then, there was a shift away from reliance on tax farming and toward levies-based censuses conducted by city governments and Roman officials. By the late Roman Empire, as citizenship was granted to provincial elites and soldiers, it became increasingly difficult politically to justify a tributary fiscal regime that imposed the heaviest tax burden on the provinces. Uniform taxes collected by a bureaucracy were established by the end of the third century, despite conflict with provincial 
elites who had assessed and allocated local taxes. Universal taxation saved the empire, except in Western Europe, which fell prey to invaders.

The two chapters on imperial China, by the historians Mark Lewis and Kent Deng, show that per capita taxes in the Chinese Empire were almost always low. That was the pattern set when the first dynasty to unify Chinathe Qin-rapidly collapsed after imposing heavy taxes. There were other reasons for the low taxes as well, besides fear of the sort of political instability and popular revolt that brought about the quick demise of the Qin. The dynasties that ruled the empire faced few peer states in East Asia and so did not have to raise taxes to fight powerful external enemies, and low taxes fit Confucian ideals of benevolent rule. The Chinese emperors also feared that high taxes would allow local officials to siphon off more of the government's revenue, because in a large empire it was hard to monitor local tax collection and local government spending. Here, the argument echoes similar claims made by economic historians Tuan-Hwee Sng and Chiaki Moriguchi (Sng 2014; Sng and Moriguchi 2014), who maintain that the difficulties of monitoring officials in a large empire like China allowed officials to exploit taxpayers. To limit the exploitation and prevent revolts, the Chinese emperors therefore kept taxes low.

In the history of imperial China, there were two major exceptions to the pattern of low taxes: the Song Dynasty (960-1279) and the Qing Dynasty after roughly 1850. To explain the higher taxes under the Song, Kent Deng points to external military threats and growing domestic trade. Recent work by Guanglin Liu (Liu 2015a, 2015b) points in the same direction and also argues that living standards were rising in Song China. But the progress was all snuffed out by the Mongol invasion and the two subsequent dynasties, the Yuan (1271-1368) and the Ming (1368-1644).
In the second period of high taxes, the late Qing Dynasty, China faced foreign threats and empire-wide social unrest, which devastated the imperial financial system. To make war on the rebels, Qing officials took two steps that were unprecedented in Chinese history: they imposed heavy new indirect taxes on commerce and they borrowed money abroad. But the central government lost control of most provinces, which fell into the hands of local military commanders, leaving late Qing China heading for what Deng suggests was either de facto federalism or "downright feudalism."

The third section of the book examines divergent trends among established fiscal regimes in the Middle East, Europe, and Japan. Historian John Haldon's chapter traces what happened to the fiscal system as the Roman Empire disintegrated in Western Europe, but survived as the Byzantine Empire in the eastern Mediterranean. In what became medieval Western Europe, tax collection withered away. State income and bureaucracy disappeared, and all that was left were the king's domain and grants of land and powers to mighty local elites. The Byzantine Empire, by contrast, preserved both the Roman bureaucracy and the Roman Empire's land taxes. With the resulting revenue devoted to war, the Byzantine Empire expanded for a while. But Muslim forces halted its expansion and forced the empire to shrink, and although the empire began to tax commerce too, western crusaders sacked Constantinople in 1204 and put an end to its military preeminence. The empire was finally conquered by the Ottomans in 1453.

The early Islamic state also preserved Roman taxation. The reason, as historian Hugh Kennedy explains, was not because of any sentimental attachment to the Roman model, nor because there was a bureaucracy that the Muslims continued to use out of institutional inertia. Rather, it was because 
the land-tax setup worked, although it came to an end in the tenth century.

Metin Cosgel's chapter on the Ottoman Empire outlines a simple economic model to explain Ottoman taxation. Beginning in the fourteenth century, the empire expanded greatly in the Middle East, the Balkans, and around the Mediterranean, and as it grew, the Ottoman emperors confronted new political constraints and new collection and monitoring costs in the territory they added. Cosgel's model takes up the emperor's problem and seeks to explain why tax levels varied from place to place and why what was taxed varied greatly from activity to activity. Collection and monitoring costs turn out to be the explanation in what was taxed; taxes focused on activities that were easily observable. For similar reasons, tax revenues were often assigned to local governments because that reduced the cost of transporting money. As for the political constraints the emperor confronted, they are the reason existing fiscal structures were often left in place-namely, to avoid rebellions. They were also the motive for choosing local leaders to be tax collectors. Doing so rewarded these local leaders with a share of tax revenue, but the policy was appealing because it put their comparative advantage as local leaders to work in establishing the legitimacy of Ottoman rule.

Historian Philip Brown covers state building and the development of the fiscal system in early modern Japan. Early steps toward a centralized state in medieval Japan were reversed, and in the sixteenth century, the country fell in to civil war between regional leaders. By the end of the century, three of the leaders unified Japan under what, in the seventeenth century, became the rule of the Tokugawa Shoguns. But the rule of the Shoguns, which lasted into the nineteenth century, was not centralized. Akin to a federal state, it left enormous powers to local overlords, the daimyo. Although the Shogun controlled foreign policy and could keep the daimyo from challenging him or fighting one another, tax revenues remained in the hands of the daimyo, who bargained over what would be taxed and how taxes would be collected. There was no centralization of the fiscal system and no government borrowing or formal government budgets, either.

The fourth section of the book takes up the fiscal systems of classical Athens, the other classical Greek city-states, and medieval city-states and Europe. All were innovative. Although the ancient Greek city-states spent a significant fraction of public revenue on the military, historian Emily Mackil argues that war was, nonetheless, not the major driver of their fiscal and political development, in contrast to what happened in early modern Europe. Taxes funded a variety of public goods and services-not just defense: in Delphi and Teos, for instance, the salary of a public doctor; on the islands of Samos or Delos, grain to be distributed to citizens. Greek city-states borrowed, and not only to pay for wars; the provision of grain also caused the city-states to incur debt. And there is yet another contrast to early modern Europe, where most states were run by autocratic kings and princes, decisions about taxation were reached via negotiation with citizens.

The same was true of Athens, the biggest ancient Greek city-state, as the political scientist Josiah Ober demonstrates in his chapter. Athens was an unusually egalitarian democracy, at least for the free, native, male citizens who made up about 12 percent of the population. In contrast to early modern Europe, where the wealthy often escaped taxation, the rich in Athens did pay taxes, which went not just for national defense, but to sustain the state religion and keep the government running, too. Poorer citizens did not owe the major direct taxes, and the government would pay them for serving in the military, attending religious festivals, and doing government work. 
Like their counterparts in ancient Greece, city-states in medieval Europe were also able to borrow, as political scientist David Stasavage shows in his chapter, and the loans they floated (so he argues) gave rise to modern public debt. The reason the medieval city-states could and did borrow was simple. They had reason to borrow because their expenditures often soared, typically when they were fighting wars. They collected taxes not in kind, but in money that could be used to repay creditors. And they had representative institutions that were run by merchants who had, themselves, purchased government debt and so would work to ensure that tax revenue would go to repay the city-state's loans. With the representative institutions reassuring lenders that they would be repaid, the medieval city-states were able to float loans.

The final two chapters of the book are comparative. In a chapter on large empires, the historian Peter Bang notes that these empires usually imposed low per capita taxes. That was true, for example, in the Roman Empire, the Ottoman Empire, and imperial China. These empires also faced a common problem. They typically had small, centrally controlled administrations and they therefore had to depend on help from local elites, who had to be rewarded for their assistance. The problem was how to prevent the elites from siphoning off so many resources that they would become rivals to the central authority. One way to keep the elites from growing too powerful was limit their access to military power and to revenue from agriculture, which in large premodern empires was usually the largest sector of the economy.

Finally, the sociologist Edgar Kiser and the political scientist Margaret Levi (both well-known for prior work on the political economy of premodern states, including Levi 1988, Kiser and Kane 2001, and Kiser and Cai 2003) evaluate what emerges from all these case studies and what topics deserve more research. They, too, note that taxes appear to be low in large empires, and call for a more precise baseline against which the level of taxes can be judged. They also call for more study of expenditures. Unlike the states in early modern Europe, premodern states elsewhere sometimes spent tax revenue on things other than war. The patterns of spending deserve study, as do the alternative ways to pay for the goods and the services that premodern states provided — not just by expending tax revenue, but by borrowing, collecting tribute from conquests, or drawing income from a ruler's domain. Kiser and Levi also call for attention to the negotiation involved in premodern fiscal systems, even when they were autocracies. Taxpayers could migrate or hide income if taxes were too heavy, and tax collectors often had enough power to pocket tax revenue. Governments had to get both the taxpayers and the tax collectors to cooperate, and Kiser and Levi argue that winning the quasi-voluntary compliance of the taxpayers was often critical. The quasi-voluntary compliance, they maintain, depended on having the government avoid corruption and deliver the public goods that promised in return for taxes. If the government failed to do that, tax revenues could shrivel up.

\section{Questions Raised by the Book}

Fiscal Regimes and the Political Economy of Premodern States raises a number of important questions. It takes the first step toward answering them, but there is much more research to do, on both government expenditures and taxation.

For expenditures, the key question that the book poses is why some premodern states spent tax revenue on things other than war. Defense is an essential public good, and war spending dominated the budgets of many of the premodern states surveyed in Fiscal Regimes and the Political Economy 
of Premodern States. But some states (imperial China, the Inca Empire, states in the ancient Near East, and the city-states of ancient Greece) devoted funds to infrastructure, religion, or famine relief, and another (the Aztec Empire) refrained from raising taxes to increase the size of the army. If military expenditures were high, the cause was likely either the existence of major foreign threats (which might be minimal for large hegemonic empires that intimidated their neighbors) or the incentives created by a political system in which leaders (such as the kings of early modern Europe) could go to war without bearing the full costs of the fighting. The rarity of famine relief outside of republican city-states can be traced back to autocratic government that limited political voice (Lindert 2004). But how do we account for those premodern states that did spend on infrastructure and religion, and for autocratic regimes such as imperial China (Will and Wong 1991) that did provide famine relief? And if states did not pay for infrastructure, religious expenses, or relief in times of dearth, did local governments? Or were those tasks left to private entrepreneurs, pious donors, or generous members of one's own family via a process that was shaped by history (as has happened in modern times in Latin America, according to Arroyo, Abad, and Lindert 2017)?

With taxation, the first question is how tax systems arose in the first place. Getting people to pay taxes means overcoming a freerider problem, and although a ruler with an army can compel them to fork money over, that is not easy without some initial revenue to mobilize the army. Warlords with armed followers who live off of plunder have an advantage here, but even they have to contend with tax evasion or migration by potential taxpayers, as contemporary evidence from Africa shows (Sánchez de la Sierra 2013). The problem is not only historical. It arises in development economics, because many poor countries lack the capacity to collect much tax revenue and so cannot provide essential public goods such as security or public health (Bates 2001; Besley and Persson 2009, 2010). Historically, compulsion played a role, but so did leaders who could convince people that taxes would, in fact, be used to furnish essentials such as security or a stable means of exchange. The historical evidence here in fact fits the evidence from public-goods experiments, where outcomes depend on the recent history of play and can change if participants become convinced that others will contribute (Hoffman 2015a, 2015b; Arifovic and Ledyard 2012). It also exemplifies the sort of negotiation that Kiser and Levi discuss in their chapter.

In polities that did manage to impose taxation, what dictated the design of their fiscal systems? What was the political economy behind the government's taxation and spending? Establishing taxation in premodern states often involved putting together a coalition of elites who benefited from a particular tax regime, but since redistributive coalitions are often unstable, what held the coalitions together? What made the rest of the population cooperate? Compulsion, a belief that the fiscal system was legitimate, or the simple fact the state provided enough essential public goods to keep taxpayers from migrating or rebelling? And was the fiscal system an accident of history and existing social and political institutions? Or was it created by a political leader who was pursuing an objective (for instance, raising money to win a war) in the face of political constraints and a lack of information about the behavior of elites and taxpayers?

That is, at bottom, a mechanism-design problem, and the question then is whether either a careful analysis of the history or an application of mechanism design or other economic theory (or perhaps the use of history and economic theory combined, as in Rosenthal 1998) can make sense of the 
political economy of premodern fiscal systems and explain why tax rates varied across time and across states. The variation in tax revenues and government spending (particularly military expenditures) should, in turn, shed light on the rise and fall of states and their expansion and contraction. Heavy taxes (including conscripted military labor services) provoked revolts, but they also allowed a state to defend itself and defeat and swallow up military competitors (Levine and Modica 2013). In the eighteenth century, when Britain was only beginning to industrialize, it collected far more tax revenue per capita than China or France, and its taxes were a higher share of national income, too. Britain's huge tax revenues, in turn, go a long way to explaining why the British defeated Napoleon and why the British Empire expanded around the world.

Although limited political voice blocked redistribution in most premodern autocracies, there are instances of autocracies distributing resources to the populace. The Inca Empire provided the general population with coca and capsicum peppers, and in Rome, the Emperor doled out subsidized food. How do we explain the instances where autocracies did redistribute? And were taxes ever progressive?

Readers of Fiscal Regimes and the Political Economy of Premodern States will also wonder about how premodern fiscal systems affected economic growth and financial development. Sustained economic growth was out of the question, for all of the political regimes surveyed in book preceded the Industrial Revolution except for the late Qing Dynasty in China. But the fiscal systems could have raised or lowered the level of per capita income, as in a simple Solow model without technical change. The political economy of the fiscal systems could have also promoted the development of financial markets. Because the rare instances of premodern states with government debt (city-states in ancient Greece and medieval Europe) all involve representative institutions, it might seem that government borrowing required some kind of republican government. But that is clearly not the case, as the example of absolutist early modern France demonstrates (Hoffman, Postel-Vinay, and Rosenthal 2000). Yet as David Stasavage argues in his chapter, the representative institutions may have facilitated the growth of government debt, particularly if the delegates in the institutions bought the debt themselves.

\section{The Need for Systematic Data}

The questions that Fiscal Regimes and the Political Economy of Premodern States raises make it clear that we now need systematic data on taxation and government spending in premodern states. That sort of data is essential if we want to make comparisons across historical examples and reach a deeper understanding of the political economy of premodern states. The case studies in the book and in the bibliographies of each chapter give us detailed histories of premodern fiscal systems, which are an essential first step. The book also points to some common features of the premodern fiscal systems, and some striking differences, too. But if we want to get a deeper understanding of the underlying political economy, we need systematic data.

Without such data, it is, in fact, difficult even to begin assessing some of the most interesting claims in the book-for example, the claim that large empires kept per capita taxes low. Testing that claim obviously necessitates systematic comparisons across states, as Levi and Kiser point out, and so far the only systematic comparison we have involves early modern China and two European states. The ideal would be the sort of panel data set (with all the figures in comparable units) that Mark Dincecco has assembled for Europe for the years 1650-1913 (Dincecco 
2009, 2011) and put online at the Global Price and Income History website (gpih. ucdavis.edu). But we also need comparisons with incomes. Were per capita taxes low, for instance, relative to per capita income?

So what sort of systematic data would it be possible to collect? Although time series of annual tax receipts or government expenditures by category are out of the question, it should be possible to put together limited quantitative data, such as periodic estimates of total tax receipts per capita or total government spending per capita (in gold, silver, man-hours of labor, or kilograms of a major commodity such as grain), along with measures of what the spending paid for, such as the number of soldiers mobilized or kilometers of fortifications constructed or canals dug per year or century, much of which could be taken from archeological evidence. Conceivably, the per capita tax and spending figures could then be combined with daily wages, if they are available, or with estimates of per capita GDP or per capita food consumption. Estimates for GDP per capita are now being pushed back to the Middle Ages in parts of Europe and China (Broadberry et al. 2015; Broadberry, Guan, and Li 2017; van Zanden, Luiten, and van Leeuwen 2012), so the goal here is not impossible; in fact, Fiscal Regimes and the Political Economy of Premodern States already contains estimates of taxes as a fraction of GDP in the early Roman Empire and government expenditures as a fraction of GDP in ancient Rome. Similarly, counts of soldiers could be compared to population estimates in order to determine what fraction of the populace the army mobilized. It might be possible to make similar estimates of the fraction of the labor force that was channeled into the government building projects, whether they involved construction of forts, canals, or roads. There would obviously be huge gaps in all this data, but it might still be feasible to carry out this sort of systematic estimation once a century for individual states, in the way that Ian Morris has done for other evidence from ancient civilizations (Morris 2010, 2013).

Qualitative data could be turned into systematic econometric evidence, too: Do representative institutions exist? Does the state borrow and if so, only for war? Does it provide famine relief or pay to construct infrastructure or churches? Again, some of the answers could come from archeology. When assembled in a systematic way (again with what might be only one observation every century for a particular state), this sort of data could be used to determine when representative institutions or public debt arise.

\section{Formal Models}

Getting a deeper understanding of the political economy of premodern states will also require formal models. It is clear (particularly from the discussion in the chapters by Cosgel and by Kiser and Levi) that the politics in Fiscal Regimes and the Political Economy of Premodern States revolves around a principal-agent problem, in which a political leader who makes decisions about taxes or spending in order to achieve some goal while taking into account political constraints and the actions of agents, who might be officials, members of the social or political elite, subjects, or even voters. The leader may know some things about the agents, but not everything-for instance, whether the officials exploit taxpayers. The question then is whether mechanism design can make sense of premodern fiscal systems. Since the leaders often made decisions about war, it would also be worthwhile applying models of conflict (Garfinkel and Skaperdas 2007). Such models already make it clear why premodern leaders who avoided the costs of fighting were so likely to go to war (Jackson and Morelli 2007), and they could also be utilized to analyze political change (Hoffman 2015b). 
Some of the political economy of the premodern states, of course, can easily be understood without any sort of formal model. It is clear, for example, why the Inca Empire did not impose labor duties on untrustworthy coastal populations and why the Aztec Empire did not levy taxes in distant provinces. The populations in the distant and coastal districts had an exit option: they might more easily rebel or move away. In addition, the collection costs would be too high. Similar causes kept net taxes low for local elites living near the frontiers of early modern France. They could bargain for lower taxes or a share of any tax increase, and as a result, the central government-even under an absolutist king-would collect less.

But other questions about the political economy of the premodern states would benefit from having a formal model. Two such questions immediately come to mind. The first concerns how taxes are collectedwhether that is the job of officials or whether tax collection is privatized and left to tax farmers, who can also lend the government money with the loans secured by the taxes they collect. Officials appear late in the early modern period Europe, but they date back centuries in China. Service as officials in the Chinese Empire provided local elites with rewards and loosened their ties to local society. That had huge consequences, because it helped keep the Chinese Empire intact even when it was invaded, in contrast to the Roman Empire, where local elites did not depend on government service for rewards (Burbank and Cooper 2010, pp. 54-9).

A formal model of when taxes are farmed out and when bureaucracies of officials are created would therefore be important. A simple principal-agent model with an agent who bids on collecting taxes might be a place to start. It might suggest that as the government grew in size, the agent would hesitate to bid if the profits from collecting taxes were correlated with the returns on the agent's other assets. The government could break the task of tax collection into pieces, but at some point, economies of scale in supervision might make it better for the government to hire multiple agents and pay them a salaryin other words, create a bureaucracy of officials. Recruitment of the officials could also bring political benefits, as in China. A formal model of the whole process - and how it was affected by exogenous variables such as the size of the country — would, in turn, allow one to explain when taxes are farmed and when revenue bureaucracies are created.

Another way to formulate the same problem would be to consider a government that is selling private entrepreneurs the rights to collect large or small amounts of tax revenue. Although the entrepreneurs know what the taxes are worth, government does not, because it lacks a fiscal bureaucracy. But the government can vary the amount of tax rights that it sells (for instance, rights to a sales tax in large or small number of cities) and the price that it charges for the tax rights. If we make some simplifying assumptions about this mechanism-design problem, the government will do best by offering an advantageous deal to entrepreneurs who collect a large amount of taxes and squeezing those who collect small amounts of taxes until they are indifferent between collecting taxes and doing something else. The implication is that if governments farmed taxes, we should see them selling off some large packages of tax rights. Whether they do that, however, will also depend on the political power of tax farmers and whether they can accumulate enough capital to take on a large tax farm. Entrepreneurs in early modern France, for instance, were able to take on large tax farms, but they had serious trouble doing the same thing in the Ottoman Empire. That may have helped the French win wars but it also contributed to the French Revolution (Balla and Johnson 2009).

The second question that deserves to be analyzed with a formal model is explaining 
why per capita taxes were low in large states such as imperial China, the eighteenth century Ottoman Empire, or the Roman Republic. The first step here is gathering the systematic data needed to verify that per capita taxes actually were lower in large states and to measure accurately how much lower they were, particularly relative to per capita income. But the next step would be using a model to analyze the relationship between state size and tax levels. The starting point might be the mechanism-design problem with the leader who seeks tax revenue-for example, because he is considering whether to go to war. The leader has to consider whether taxpayers will rebel, and they might be more likely to revolt in distant provinces. But the leader also has to take into account the behavior of agents, such as tax collectors or elites entrusted with gathering local taxes. Both might exploit taxpayers (particularly in distant provinces) by forcing them to hand over bribes, and if the exploitation was added to heavy taxes, it could raise the risk of rebellion even higher. The result would be a model similar to the one that Sng and Moriguchi use to explain low tax levels in China (Sng 2014; Sng and Moriguchi 2014), although it would have to be extended to add decisions about war.

The issue is whether such a model could be generalized beyond China. It would take state size as given and then presumably predict that tax levels would always be lower in larger states. But it would leave open the question of how to explain state size (Alesina and Spolaore 2003).

The alternative would be to seek historical explanations both for state size and tax levels. A large state like the Chinese Empire or the early Roman Empire would create a hegemon that would discourage neighbors from attacking. Such a state might be able to avoid imposing heavy taxes to fight wars, particularly if it drained tribute from recently conquered territory, as the Roman Republic and early Roman Empire did. But perhaps the most promising path to a deeper understanding, though, would be to combine the history, the systematic data, and the formal models. That is likely the best path toward a deeper understanding of the political economy of premodern states.

\section{REFERENCES}

Alesina, Alberto, and Enrico Spolaore. 2003. The Size of Nations. Cambridge, MA: MIT Press.

- Arifovic, Jasmina, and John Ledyard. 2012. "Individual Evolutionary Learning, Other-Regarding Preferences, and the Voluntary Contributions Mechanism." Journal of Public Economics 96 (9-10): 808-23.

Arroyo Abad, Leticia, and Peter H. Lindert. 2017. "Fiscal Redistribution in Latin America since the Nineteenth Century." In Has Latin American Inequality Changed Direction? Looking Over the Long Run, edited by Luis Bertola and Jeffrey Williamson, 243-82. Cham: Springer.

- Balla, Eliana, and Noel D. Johnson. 2009. "Fiscal Crisis and Institutional Change in the Ottoman Empire and France." Journal of Economic History 69 (3): 809-45.

Bates, Robert H. 2001. Prosperity and Violence: The Political Economy of Development. New York: W. W. Norton \& Company.

-Besley, Timothy, and Torsten Persson. 2009. "The Origins of State Capacity: Property Rights, Taxation, and Politics." American Economic Review 99 (4): 1218-44.

-Besley, Timothy, and Torsten Persson. 2010. "State Capacity, Conflict, and Development.” Econometrica 78 (1): 1-34.

Bonney, Richard. 1995. Economic Systems and State Finance. Oxford and New York: Oxford University Press.

Bonney, Richard. 1999. The Rise of the Fiscal State in Europe c. 1200-1815. Oxford and New York: Oxford University Press.

- Brandt, Loren, Debin Ma, and Thomas G. Rawski. 2014. "From Divergence to Convergence: Reevaluating the History behind China's Economic Boom." Journal of Economic Literature 52 (1): 45-123.

Broadberry, Stephen, Bruce M. S. Campbell, Alexander Klein, Mark Overton, and Bas van Leeuwen. 2015. British Economic Growth, 1270-1870. Cambridge and New York: Cambridge University Press.

Broadberry, Stephen, Hanhui Guan, and David Daokui Li. 2017. "China, Europe and the Great Divergence: A Study in Historical National Accounting, 980-1850." University of Oxford Discussion Paper in Economic and Social History 155 (April).

Burbank, Jane, and Frederick Cooper. 2010. Empires in World History: Power and the Politics of Difference. Princeton and Oxford: Princeton University Press.

Carter, Susan B., Scott Sigmund Gartner, Michael R. Haines, Alan L. Olmstead, Richard Sutch, and Gavin 
Wright, eds. 2006. Historical Statistics of the United States. Cambridge and New York: Cambridge University Press.

-Dincecco, Mark. 2009. "Fiscal Centralization, Limited Government, and Public Revenues in Europe, 1650-1913." Journal of Economic History 69 (1): 48-103.

Dincecco, Mark. 2011. Political Transformations and Public Finances: Europe, 1650-1913. Cambridge and New York: Cambridge University Press.

Garfinkel, Michelle R., and Stergios Skaperdas. 2007. "Economics of Conflict: An Overview." In Handbook of Defense Economics: Volume 2: Defense in a Globalized World, edited by Todd Sandler and Keith Hartley, 649-709. Amsterdam: Elsevier, North-Holland.

-Hoffman, Philip T. 2015a. "What Do States Do? Politics and Economic History." Journal of Economic History 75 (2): 303-32.

Hoffman, Philip T. 2015b. Why Did Europe Conquer the World? Princeton and Oxford: Princeton University Press.

Hoffman, Philip T., and Kathryn Norberg, eds. 1994. Fiscal Crises, Liberty, and Representative Government 1450-1789. Stanford: Stanford University Press.

Hoffman, Philip T., and Jean-Laurent Rosenthal. 1997. "The Political Economy of Warfare and Taxation in Early Modern Europe: Historical Lessons for Economic Development." In The Frontiers of the New Institutional Economics, edited by John N. Drobak and John V. C. Nye, 31-55. San Diego: Academic Press.

Hoffman, Philip T., Gilles Postel-Vinay, and Jean-Laurent Rosenthal. 2000. Priceless Markets: The Political Economy of Credit in Paris, 1660-1870. Chicago and London: University of Chicago Press.

- Jackson, Matthew O., and Massimo Morelli. 2007. "Political Bias and War." American Economic Review 97 (4): 1353-73.

-Karaman, K. Kivanç, and Şevket Pamuk. 2010. "Ottoman State Finances in European Perspective, 15001914." Journal of Economic History 70 (3): 593-629.

-Kiser, Edgar, and Yong Cai. 2003. "War and Bureaucratization in Qin China: Exploring an Anomalous Case." American Sociological Review 68 (4): 511-39.

-Kiser, Edgar, and Joshua Kane. 2001. "Revolution and State Structure: The Bureaucratization of Tax Administration in Early Modern England and France." American Journal of Sociology 107 (1): 183-223.

Levi, Margaret. 1988. Of Rule and Revenue. Berkeley: University of California Press.

Levine, David K., and Salvatore Modica. 2013. "Conflict, Evolution, Hegemony, and the Power of the State." National Bureau of Economic Research Working Paper 19221.

Lindert, Peter H. 2004. Growing Public: Social Spending and Economic Growth since the Eighteenth Century. Cambridge and New York: Cambridge University Press.

Liu, William Guanglin. 2015a. The Chinese Market
Economy, 1000-1500. Albany: SUNY Press.

Liu, William Guanglin. 2015b. "The Making of a Fiscal State in Song China, 960-1279." Economic History Review 68 (1): 48-78.

Mathias, Peter, and Patrick O'Brien. 1976. "Taxation in Britain and France, 1715-1810: A Comparison of the Social and Economic Incidence of Taxes Collected for the Central Governments." Journal of European Economic History 5 (3): 601-50.

Morris, Ian. 2010. Why the West Rules-For Now: The Patterns of History, and What They Reveal about the Future. New York: Farrar, Straus, and Giroux.

Morris, Ian. 2013. The Measure of Civilisation: How Social Development Decides the Fate of Nations. Princeton and Oxford: Princeton University Press.

O’Brien, Patrick K. 1988. "The Political Economy of British Taxation, 1660-1815." Economic History Review 41 (1): 1-32.

Ormrod, William, Margaret Bonney, and Richard Bonney, eds. 1999. Crises, Revolutions and Self-Sustained Growth: Essays in European Fiscal History, 1130-1830. Stamford: Shaun Tyas.

Rosenthal, Jean-Laurent. 1992. The Fruits of Revolution: Property Rights, Litigation, and French Agriculture, 1700-1860. Cambridge and New York: Cambridge University Press.

Rosenthal, Jean-Laurent. 1998. "The Political Economy of Absolutism Reconsidered." In Analytic Narratives, edited by Robert H. Bates, Avner Greif, Margaret Levi, Jean-Laurent Rosenthal, and Barry R. Weingast, 64-108. Princeton and Oxford: Princeton University Press.

Sánchez de la Sierra, Raúl. 2013. "On the Origin of States: Stationary Bandits and Taxation in Eastern Congo." Unpublished.

Schumpeter, Joseph. 1918. Die Krise des Steuerstaats. Graz; Leuschner and Lubensky.

Sng, Tuan-Hwee. 2014. "Size and Dynastic Decline: The Principal-Agent Problem in Late Imperial China, 1700-1850." Explorations in Economic History 54: 107-27.

-Sng, Tuan-Hwee, and Chiaki Moriguchi. 2014. “Asia’s Little Divergence: State Capacity in China and Japan before 1850." Journal of Economic Growth 19 (4): 439-70.

Tilly, Charles. 1990. Coercion, Capital and European States, AD 990-1992. Cambridge, MA and Oxford: Blackwell.

van Zanden, Jan Luiten, and Bas van Leeuwen. 2012. "Persistent But Not Consistent: The Growth of National Income in Holland 1347-1807." Explorations in Economic History 49 (2): 119-30.

Will, Pierre-Etienne, and R. Bin Wong. 1991. Nourish the People: The State Civilian Granary System in China, 1650-1850. Ann Arbor: University of Michigan Press.

Yun-Casalilla, Bartolomé, and Patrick K. O'Brien. 2012. The Rise of Fiscal States: A Global History 1500-1914. Cambridge and New York: Cambridge University Press. 